\title{
Optimizing Embryogenic Callus and Embryo Growth of a Synthetic Seed System for Sweetpotato by Varying Media Nutrient Concentrations
}

\author{
Raymond P. Chée', Daniel I. Leskovar ${ }^{2}$, and Daniel J. Cantliffe \\ Vegetable Crops Department, Institute of Food and Agricultural Sciences, University of Florida, \\ Gainesville, FL 32611 \\ Additional index words. Ipomoea batatas, nitrogen, potassium, somatic embryogenesis
}

\begin{abstract}
Embryogenic callus growth of sweetpotato [Ipomoea batatas (L.) Lam.] was selectively enhanced by subculture on basal callus proliferation medium modified to contain $15 \mathrm{mM} \mathrm{NH}_{4} \mathrm{NO}_{3}$. Embryogenic callus production was doubled on basal callus proliferation medium modified to contain $60 \mathrm{~mm}+$, while nonembryogenic callus production was reduced $40 \%$. Additions of up to $40 \mathrm{~mm} \mathrm{NaCl}$ to basal callus proliferation medium did not affect callus proliferation. The development of embryos from calli subculture to embryo production basal medium was unaffected by the $\mathrm{KCl}$ or $\mathrm{NaCl}$ treatments of the callus proliferation phase. However, embryo production was increased by subculturing callus from callus proliferation medium containing $20 \mathrm{~mm} \mathrm{NH}_{4}^{+}$to embryo production medium containing $10 \mathrm{~mm} \mathrm{NH}+$. Our results demonstrate that changes in mineral nutrition, in addition to growth regulator differences between callus proliferation and embryo production media, are important factors in sweetpotato somatic embryogenesis.
\end{abstract}

Clonal propagation via somatic embryogenesis has been proposed by Cantliffe et al. (1988) for synthetic seed production of sweetpotato. Sweetpotato somatic embryo production is accomplished in two stages (Chée and Cantliffe, 1988a). Embryogenic callus is continuously proliferated by subculture on media containing growth regulators; embryos are produced by transferring embryogenic callus to media without growth regulators. Formation of embryogenic callus was enhanced by addition of $10 \mu \mathrm{M}$ (2,4-dichlorophenoxy)acetic acid (2,4-D) and $1 \mu \mathrm{M} \mathrm{N}$ (phenylmethyl)-1 $H$-purine-6-amine (BA) (Chée and Cantliffe, 1988b). Further improvements in embryogenic callus growth and embryo production could be expected by optimizing inorganic salts in the basal medium. However, information on the mineral nutrition of embryogenic callus is insufficient (Ammirato, 1983; Vasil, 1984).

Nitrogen is quantitatively the major mineral nutrient taken up during growth of plant tissues (Marschner, 1986). Supplying N in its reduced rather than oxidized form to tissue culture likely would be more efficient for growth, since $\mathrm{NO}_{3}$ reduction is energetically expensive (Clarkson and Hanson, 1980). However, cultured cells were unable to grow on $\mathrm{NH}_{4}^{+}$as the sole $\mathrm{N}$ source when media did not include organic acids as buffers, or without continuous titration of the medium (Chaleff, 1983; Dougall and Verma, 1978; Fukunaga et al., 1978; Gamborg and Shyluk; 1970; Martinet al., 1977). This result is to be expected since $\mathrm{NH}_{4}^{+}$uptake is physiologically acidic (Marschner, 1986). The relative and absolute amounts of $\mathrm{NH}_{4}^{+}$and $\mathrm{NO}_{3}^{-}$also influence embryogenesis in cell cultures (Tazawa and Reinert, 1969). Generally, it is thought that the ionic form of $\mathrm{N}$ affects growth and nutrient uptake by altering cation-anion balance, changing organic anion accumulation and ultimately affecting medium and cytosol pH values (Marschner, 1986; Poole, 1978;

Received for publication 16 Aug. 1991. Accepted for publication 10 Feb. 1992 Florida Agricultural Experiment Station, Journal Series no. R-9657. This work was supported in part by an IFAS/Gas Research Inst. cooperative grant. The cost of publishing this paper was defrayed in part by the payment of page charges. Under postal regulations, this paper therefore must be hereby marked advertisement solely to indicate this fact.

'SIGMA Chemical Co., Cell Culture, PO Box 14508, St. Louis, MO 63178. ${ }^{2}$ Texas Agr. Expt. Sta., Texas A\&M Univ., 1619 Gamer Field Rd., Uvalde, TX 78801.
Spanswick, 1981). Ammonium directly competes for uptake with $\mathrm{K}$, which is the major cation involved in maintaining cation-anion balance and the most common counterion for organic anions (Marschner, 1986). Potassium is also required in the cytoplasm for active conformation of numerous enzymes and maintenance of osmotic potential (Clarkson and Hanson, 1980). External $\mathrm{N}$ and $\mathrm{K}$ ions may also influence growth through their direct effects on the plasmalemma proton pump that is stimulated preferentially by $\mathrm{K}+, \mathrm{NH}_{4}^{+}$, and $\mathrm{Na}^{+}$, in that order (O'Neill and Spanswick, 1984).

In this study we evaluated the effects $\mathrm{oNH}_{4}^{+}, \mathrm{NO}_{3}^{-}$, and $\mathrm{K}^{+}$, and their companion ions $\mathrm{Na}^{+}$and $\mathrm{Cl}^{-}$, on embryogenic callus and embryo growth in sweetpotato.

\section{Materials and Methods}

Embryogenic callus of sweetpotato 'White Star' was obtained from shoot apices and proliferated as reported by Chée and Cantliffe (1988b). The basal medium contained the inorganic salts of Murashige and Skoog (1962), $500 \mu \mathrm{m}$ myo-inositol, 5 $\mu \mathrm{M}$ thiamine $\cdot \mathrm{HCl}, 10 \mu \mathrm{M}$ nicotinic acid, $5 \mu \mathrm{m}$ pyridoxine $\cdot \mathrm{HCl}$, $87.6 \mathrm{~mm}$ sucrose, and $0.6 \% \mathrm{w} / \mathrm{v}$ Phytagar (GIBCO Laboratories, Grand Island, N.Y.). Callus proliferation media (CP) contained $10 \mu \mathrm{M}$ 2,4-D and $1 \mu \mathrm{M}$ BA (Chée and Cantliffe, 1988b); embryo production media (EP) were hormone free (Chée and Cantliffe, 1988a). The basal CP and EP media were modified, as indicated for each experiment, by using combinations of $\mathrm{NH}_{4} \mathrm{NO}_{3}, \mathrm{NH}_{4} \mathrm{Cl},\left(\mathrm{NH}_{4}\right)_{2}$ citrate, $\mathrm{NaNO}_{3}, \mathrm{KNO}_{3}, \mathrm{KCl}$, and $\mathrm{NaCl}$ to obtain the desired balance of ions. The $\mathrm{pH}$ was adjusted to 5.8 with $1 \mathrm{~N} \mathrm{NaOH}$ before autoclaving at $121 \mathrm{C}$ and $110 \mathrm{kPa}$ for $15 \mathrm{~min}$.

Embryogenic callus fragments (calli), $1 \mathrm{~mm}$ in diameter (1 mg average fresh weight), of 8-week-old cultures were used in the experiments. Calli were placed individually on $12 \mathrm{ml}$ of medium contained in $60 \times 15-\mathrm{mm}$ plastic petri dishes. There were 10 dishes per treatment. Incubation was at $27 \mathrm{C}$ in the dark with unmonitored light interruptions during daily observations. Embryogenic and nonembryogenic callus production on CP media was determined using fresh weights at 8 weeks. Sweetpotato embryogenic callus is firm, yellow, and opaque; nonembryogenic callus is friable, white, and translucent (Chée and Cantliffe, 1988b; Liu and Cantliffe, 1984). Embryo production on 
EP media was determined by counting embryos at the heart, torpedo, and cotyledonary stages of development at 21 days (Chée and Cantliffe, 1988a).

In Expt. I, we investigated $\mathrm{N}$ form on callus growth. Basal $\mathrm{CP}$ medium was modified to contain $\mathrm{NH}_{4} \mathrm{NO}_{3}$ at 2.5, 5.0, 7.5, 10,15 , or $20 \mathrm{~mm}$. The other $\mathrm{N}$ source of basal CP medium was $20 \mathrm{mM} \mathrm{KNO}_{3}$. Calloused in the first passage were obtained on basal $\mathrm{CP}$ medium, which contained $20 \mathrm{~mm} \mathrm{NH}_{4} \mathrm{NO}_{3}$. After 8 weeks, calli were subculture to the same respective $\mathrm{NH}_{4} \mathrm{NO}_{3}$ treatments for the second passage.

In Expt: II, we compared $\mathrm{K}$ concentration on callus growth. Basal CP medium was modified to contain $\mathrm{K}^{+}$at $6.25,11.2$, $16.2,21.2,31.2,41.2,51.2$, or $61.2 \mathrm{~mm}$. In each case 1.25 $\mathrm{mm}$ of $\mathrm{K}^{+}$came from $\mathrm{KH}_{2} \mathrm{PO}_{4}$ of the basal $\mathrm{CP}$ medium. The four lower $\mathrm{K}^{+}$concentrations were obtained using $\mathrm{KNO}_{3}$. The four higher $\mathrm{K}^{+}$concentrations were obtained using $\mathrm{KNO}_{3}$ at 20 $\mathrm{mm}$ and $\mathrm{KCl}$. The $\mathrm{N}$ levels were complemented with $\mathrm{NaNO}_{3}$ to a total of $60 \mathrm{~mm}$ for each treatment. Calli used in the first passage originated on basal CP medium that contained $20 \mathrm{~mm}$ $\mathrm{K}^{+}$. After 8 weeks, calli were subculture to the same respective $\mathrm{K}^{+}$treatments for the second passage. Calli of each passage were subculture onto basal EP medium to test for residual effects of the $\mathrm{K}^{+}$treatments on subsequent embryo production.

In Expt. III, we compared the effect of $\mathrm{NaCl}$ with that of $\mathrm{KCl}$ on callus growth. Basal $\mathrm{CP}$ medium was supplemented with $\mathrm{NaCl}$ or $\mathrm{KCl}$ at $10,20,30$, or $40 \mathrm{~mm}$. The basal $\mathrm{CP}$ medium contained $20 \mathrm{mM} \mathrm{K}^{+}, 6 \mathrm{mMCl}^{-}$and no $\mathrm{Na}^{+}$. The calli used were subculture from basal $\mathrm{CP}$ medium. The residual effects of $\mathrm{NaCl}$ and $\mathrm{KCl}$ on subsequent embryo production were tested by subculturing calli onto EP basal medium.

In Expt. IV, we evaluated $\mathrm{N}$ source and level on embryo production. Basal EP medium was modified to contain $\mathrm{NH}_{4} \mathrm{NO}_{3}$ at 2.5, 5.0, 7.5, 10, 15, and $20 \mathrm{~mm}$. The other $\mathrm{N}$ source of basal EP medium was $20 \mathrm{mM} \mathrm{KNO}_{3}$. The calli used were subculture from basal CP medium that contained $20 \mathrm{mM} \mathrm{NH}_{4} \mathrm{NO}_{3}$. In a replicate experiment, the calli used in each treatment were subculture from $\mathrm{CP}$ media with the same $\mathrm{NH}_{4} \mathrm{NO}_{3}$ concentrations.

In Expt. V, embryo production was compared in response to $\mathrm{NH}_{4}^{+}$and total $\mathrm{N}$ in a factorial experiment. Ammonium nitrate was withheld from the basal EP medium and $\left(\mathrm{NH}_{4}\right)_{2}$ citrate was added at $0,2.5,5.0$, and $10 \mathrm{~mm}$ Total $\mathrm{N}$ levels of 40 and $60 \mathrm{~mm}$ were obtained by complementing the media containing $20 \mathrm{mM} \mathrm{KNO}_{3}$ with an appropriate amount of $\mathrm{NaNO}_{3}$. The calli used in the experiment were subculture from basal $\mathrm{CP}$ medium.

\section{Results and Discussion}

In the first passage of Expt. I, both embryogenic and nonembryogenic callus fresh weights were similar among $\mathrm{NH}_{4} \mathrm{NO}_{3}$ treatments (Table 1). However, upon subculture to the same $\mathrm{NH}_{4} \mathrm{NO}_{3}$ treatments in the second passage, embryogenic callus production increased to a maximum at $15 \mathrm{mM} \mathrm{NH}_{4} \mathrm{NO}_{3}$, and nonembryogenic callus production decreased as $\mathrm{NH}_{4} \mathrm{NO}_{3}$ concentration increased. Calli used in the first passage originated on $\mathrm{CP}$ medium containing $20 \mathrm{mM} \mathrm{NH}_{4} \mathrm{NO}_{3}$. Consequently, subculturing embryogenic callus on $\mathrm{CP}$ medium containing $15 \mathrm{~mm}$ instead of the $20 \mathrm{mM} \mathrm{NH}_{4} \mathrm{NO}_{3}$ of the MS salts selectively enhanced embryogenic callus proliferation. The enhanced embryogenic callus growth by increased $\mathrm{NH}_{4} \mathrm{NO}_{3}$ could be a response to increased total $\mathrm{N}$ level, $\mathrm{NH}_{4}^{+}$concentration, or $\mathrm{NH}_{4}^{+} \mathrm{NO}_{3}^{-}$ and $\mathrm{NH}_{4}^{+} / \mathrm{K}^{+}$concentration ratios.

In Expt. II, where total $\mathrm{N}$ level and $\mathrm{NH}_{4}^{+} / \mathrm{NO}_{3}^{-}$ratio were held constant, embryogenic callus growth was promoted by increased $\mathrm{K}^{+}$concentrations and decreas $\mathrm{NHH}_{4}^{+} / \mathrm{K}^{+}$ratios (Table 2). Decreasing the $\mathrm{NH}_{4}^{+} / \mathrm{K}^{+}$ratio promoted in vitro meristem initiation and growth in Vitis (Galzy, 1972). However, the combined results of Expt. I, where $\mathrm{K}^{+}$was held constant and $\mathrm{N}$ varied (Table 1), and Expt. II, where $\mathrm{N}$ was held constant and $\mathrm{K}^{+}$varied (Table 2), show an ambiguous relationship between embryogenic callus growth and $\mathrm{NH}_{4} /$ $\mathrm{K}^{+}$ratios, possibly because the varying $\mathrm{NH}_{4}^{+} / \mathrm{NO}_{-}^{-}$ratio may complicate the $\mathrm{K}^{+}-\mathrm{NH}_{4}$ relationship in Expt. I. In Expt. I, increased embryogenic callus growth corresponded to increased $\mathrm{NH}_{4}^{+} / \mathrm{K}^{+}$ratios with highest yields at $\mathrm{NH}_{4}^{+} / \mathrm{K}^{+}=$ 0.75 , while in Expt. II, increased embryogenic callus growth corresponded to decreasing $\mathrm{NH}_{4}^{+} / \mathrm{K}^{+}$ratios with highest yields at $\mathrm{NH}_{4}^{+} / \mathrm{K}^{+}=0.3$. Our results suggest that $\mathrm{K}+$ at $20 \mathrm{~mm}$ became the limiting factor for embryogenic callus growth when $\mathrm{NH}_{4}^{+}$exceeded $15 \mathrm{~mm}$ (Table 1). Cell metabolism is disrupted when $\mathrm{NH}_{4}^{+}$relatively high levels competes successfully with $\mathrm{K}^{+}$for negative charges within the cells (Marschner, 1986). Appropriately, when $\mathrm{K}^{+}$concentration was increased from 20 to $60 \mathrm{~mm}$ in the presence of $20 \mathrm{mNH}_{4}^{+}$,embryogenic callus growth was promoted (Table 2), probably because the readily exchangeable $\mathrm{K}^{+}$was then reestablished in its role in neutralizing organic and inorganic anions.

High $\mathrm{K}^{+}$concentrations promoted embryogenic callus growth whether calli were subculture from basal CP medium, containing $21.25 \mathrm{mM} \mathrm{K}^{+}$, or from $\mathrm{CP}$ media of passage 1 containing respectively the same $\mathrm{K}^{+}$levels (Table 2). Doubling the $\mathrm{K}^{+}$ concentration of the MS salts doubled embryogenic callus yields, while nonembryogenic callus growth decreased $40 \%$. Thus, subculturing calli on high-K CP medium selectively promoted embryogenic callus growth. The $\mathrm{K}$ concentration in the callus proliferation stage did not affect subsequent embryo production on basal EP medium (Table 2). The basal EP medium contained $20 \mathrm{mM} \mathrm{K}^{+}$, a concentration found optimum in embryogenesis of Daucus carota L. (Brown et al., 1976).

Nutritionally important ions are usually added to culture media in the form of sodium salts or chlorides, since $\mathrm{Na}^{+}$and $\mathrm{Cl}^{-}$ do not influence growth in many plant tissue culture systems at concentrations up to $40 \mathrm{~mm}$ (Brown et al., 1976; Heller, 1953). In Expt. III, additions of 10 to $40 \mathrm{~mm} \mathrm{NaCl}$ to $\mathrm{CP}$ media did not affect callus growth, while similar $\mathrm{KCl}$ additions promoted a linear increase in embryogenic callus production (Table 3 ). Thus, increased embryogenic callus growth can be attributed to increased $\mathrm{K}^{+}$rather than increased $\mathbf{C l}$ - concentrations. Neither $\mathrm{NaCl}$ nor $\mathrm{KCl}$ additions to $\mathrm{CP}$ media were detrimental to subsequent embryo production on EP media (Table 3).

In Expt. IV, embryo production was stimulated by decreasing $\mathrm{NH}_{4} \mathrm{NO}_{3}$ from $20 \mathrm{~mm}$ in the $\mathrm{CP}$ medium to $10 \mathrm{~mm}$ in the EP medium (Table 4). A further decrease in $\mathrm{NH}_{4} \mathrm{NO}_{3}$ was not beneficial. Embryo production was similar for all $\mathrm{NH}_{4} \mathrm{NO}_{3}$ concentrations when callus was subculture from $\mathrm{CP}$ media containing 2.5 to $20 \mathrm{~m}_{\mathrm{M}} \mathrm{NH}_{4} \mathrm{NO}_{3}$ to $\mathrm{EP}$ media with the same respective $\mathrm{NH}_{4} \mathrm{NO}_{3}$ concentration. Increased embryo production in response to decreased $\mathrm{NH}_{4} \mathrm{NO}_{3}$ between $\mathrm{CP}$ and EP media could result from decreased total $\mathrm{N}_{\text {levelNH}}{ }_{4}$, or $\mathrm{NH}_{4}^{+} / \mathrm{N}$ ratio. This was investigated in Expt. $\mathrm{V}$ where $\mathrm{NH}_{4}^{+}$was varied in the EP medium from 0 to $20 \mathrm{~mm}$ at two total $\mathrm{N}$ levels (Table 5). Total $\mathrm{N}$ did not affect embryo production within eachNH ${ }_{4}^{+}$treatment. However, overall embryo production was increased by subculturing calli from basal CP medium containing $20 \mathbf{N H H}_{4}^{+}$to EP media containing $10 \mathrm{mMNH}_{4}^{+}$.

Auxin removal has been the classical permissive trigger for 
Table 1. Callus growth in response to $\mathrm{NH}_{4} \mathrm{NO}_{3}$ concentration in sweetpotato. ${ }^{2}$

\begin{tabular}{|c|c|c|c|c|c|c|c|c|c|c|}
\hline & & & & & & & \multicolumn{4}{|c|}{ Callus fresh wt (mg)y } \\
\hline & & & & & & & \multicolumn{2}{|c|}{ Passage 1} & \multicolumn{2}{|c|}{ Passage 2} \\
\hline \multicolumn{7}{|c|}{ Treatment (mM) } & & Non & & Non- \\
\hline 2.5 & 18.8 & 1.2 & 21.3 & 23.8 & 0.13 & 0.12 & 18 & 139 & 14 & 346 \\
\hline 5.0 & 18.8 & 1.2 & 23.8 & 28.8 & 0.25 & 0.21 & 16 & 126 & 21 & 307 \\
\hline 7.5 & 18.8 & 1.2 & 26.3 & 33.8 & 0.37 & 0.29 & 19 & 171 & 37 & 146 \\
\hline 20.0 & 18.8 & 1.2 & 38.8 & 58.8 & 1.00 & 0.52 & 22 & 227 & 55 & 110 \\
\hline \multicolumn{2}{|c|}{ Significance } & & & & & & NS & NS & $\mathrm{L}^{* *} \mathrm{Q}^{*}$ & $\mathrm{~L}^{* *} \mathrm{Q}^{*}$ \\
\hline \multicolumn{2}{|c|}{ Mean (SE) } & & & & & & $19(1)$ & $172(21)$ & -- & --- \\
\hline
\end{tabular}

${ }^{2}$ Statistical analysis used the component of variance method: Significance $=\mathrm{F}$ test, $\mathrm{L}^{* *}=$ linear at $P=0.01, \mathrm{Q}^{*}=$ quadratic at $P=0.05$, NS $=$ not significant.

yInocula were 1 -mg embryogenic callus fragments; for passage 1 , calli were subcultured from callus proliferation media containing 20 mM $\mathrm{NH}_{4} \mathrm{NO}_{3}$; for passage 2 , calli were subcultured from the respective treatments of passage 1 .

Table 2. Effect of $\mathrm{K}$ concentration on callus growth in sweetpotato and residual effect on embryogenesis after callus transfer to media for embryo production. ${ }^{z}$

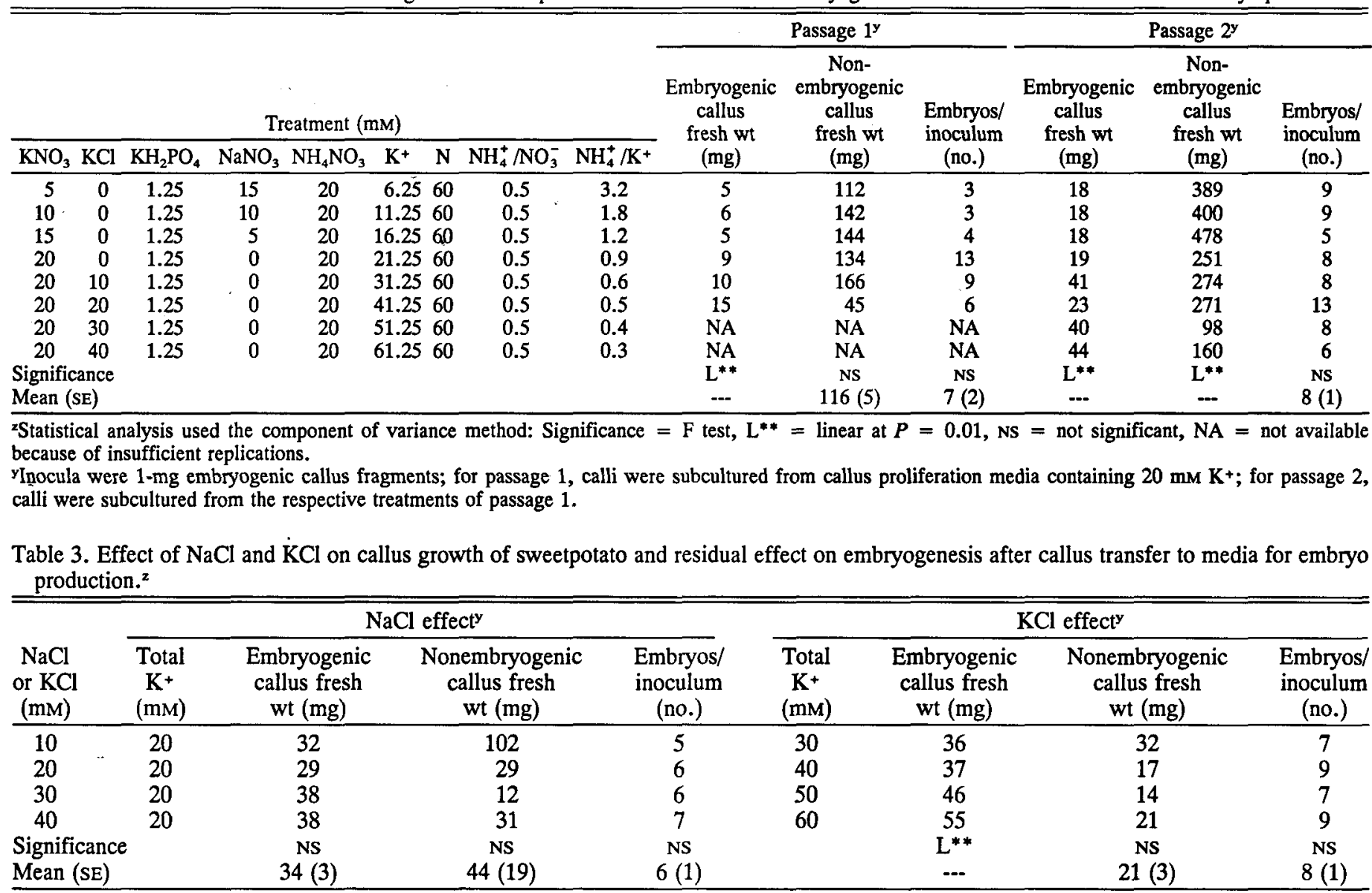

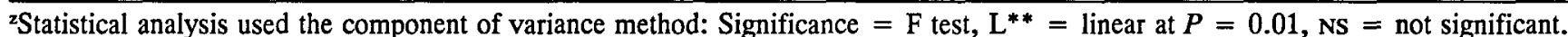

yInocula were 1-mg embryogenic callus fragments subcultured from callus proliferation media containing $20 \mathrm{mM} \mathrm{K}^{+}$.

embryo development (Ammirato, 1983). However, requirements for the reduction form of $\mathrm{N}$ for embryo initiation and maturation seem well supported (Halperin, 1966; Halperin and Wetherell, 1965; Walker and Sato, 1981; Wetherell and Dougall, 1976). In carrot cultures, ammonium additions of $10 \mathrm{~mm}$ $\mathrm{NH}_{4} \mathrm{Cl}$ to media containing 12 to $40 \mathrm{~mm} \mathrm{KNO}_{3}$ were found optimal for embryogenesis (Wetherell and Dougall, 1976). In Medicago sativa (L.), optimal somatic embryo development required a minimum of $12.5 \mathrm{mNH} \mathbf{H}_{4}$ Walker and Sato, 1981).
In alfalfa, embryo development followed 2,4-D withdrawal combined with $\mathrm{NH}_{4}^{+}$increase from a 2.6 to $5 \mathrm{~mm}$ range to a 10 to $12.5 \mathrm{~mm}$ range (Seitz Kris and Bingham, 1988; Walker and Sato, 1981). In Glycine max, embryo development required removal of 2,4-D and a coordinated decrease of $\mathrm{NH}_{4}^{+}$from 40 to $20 \mathrm{mmNH}$ nd increase $\mathrm{NO}$ from 0 to $40 \mathrm{~mm}$ (Christianson, 1985).

Here we enhanced embryo production in sweetpotato by increasing both embryogenic callus growth and embryo devel- 
Table 4. Embryo production in response to $\mathrm{NH}_{4} \mathrm{NO}_{3}$ concentration in sweetpotato and residual effect on embryogenesis of the $\mathrm{NH}_{4} \mathrm{NO}_{3}$ concentrations used in the callus proliferation phase. ${ }^{\mathrm{z}}$

\begin{tabular}{|c|c|c|c|c|c|c|c|c|}
\hline \multicolumn{7}{|c|}{ Treatment (mM) } & \multicolumn{2}{|c|}{ Embryos/inoculum ${ }^{y}$ (no.) } \\
\hline $\mathrm{NH}_{4} \mathrm{NO}_{3}$ & $\mathrm{KNO}_{3}$ & $\mathrm{KH}_{2} \mathrm{PO}_{4}$ & $\mathrm{NO}_{3}^{+}$ & $\mathbf{N}$ & $\mathrm{NH}_{4}^{+} / \mathrm{K}^{+}$ & $\mathrm{NH}_{4}^{+} / \mathrm{NO}_{3}^{-}$ & $\begin{array}{c}\text { Calli from } \\
\text { CP with } \\
20 \mathrm{mM} \mathrm{NH}_{4} \mathrm{NO}_{3}\end{array}$ & $\begin{array}{l}\text { Calli from } \\
\mathrm{CP} \text { with } \\
2.5-20 \mathrm{mM} \\
\mathrm{NH}_{4} \mathrm{NO}_{3}\end{array}$ \\
\hline 2.5 & 18.8 & 1.2 & 21.3 & 23.8 & 0.13 & 0.12 & 8.5 & 9.4 \\
\hline 5.0 & 18.8 & 1.2 & 23.8 & 28.8 & 0.25 & 0.21 & 8.9 & 18.1 \\
\hline 7.5 & 18.8 & 1.2 & 26.3 & 33.8 & 0.37 & 0.29 & 14.1 & 11.1 \\
\hline 10.0 & 18.8 & 1.2 & 28.8 & 38.8 & 0.50 & 0.35 & 17.0 & 11.2 \\
\hline 15.0 & 18.8 & 1.2 & 33.8 & 48.8 & 0.75 & 0.44 & 12.4 & 10.2 \\
\hline 20.0 & 18.8 & 1.2 & 38.8 & 58.8 & 1.00 & 0.52 & 9.4 & 7.3 \\
\hline \multirow{2}{*}{\multicolumn{2}{|c|}{$\begin{array}{l}\text { Significance } \\
\text { Mean (SE) }\end{array}$}} & & & & & & $\mathrm{Q}^{* *}$ & NS \\
\hline & & & & & & & -.. & $11.2(1.6)$ \\
\hline
\end{tabular}

${ }^{\mathrm{z}}$ Statistical analysis used the component of variance method: Significance $=\mathrm{F}$ test, $\mathrm{Q}^{* *}=$ quadratic at $P=0.01$, NS $=$ not significant.

${ }^{\mathrm{y}}$ Inocula were $1-\mathrm{mg}$ embryogenic calli fragments; $\mathrm{CP}=$ callus proliferation media.

Table 5. Embryo production in response to ammonium concentration and total $\mathrm{N}$ in sweetpotato. ${ }^{\text {Z,Y }}$

\begin{tabular}{|c|c|c|c|c|c|c|c|}
\hline \multirow[b]{2}{*}{$\begin{array}{l}\mathrm{NH}_{4}^{+} \\
(\mathrm{mM})\end{array}$} & \multirow[b]{2}{*}{$\begin{array}{c}\mathrm{K}^{+} \\
(\mathrm{mM})\end{array}$} & \multirow[b]{2}{*}{$\mathrm{NH}_{4}^{+-} / \mathrm{K}^{+}$} & \multicolumn{2}{|c|}{ Total $\mathrm{N}=40 \mathrm{mM}$} & \multicolumn{2}{|c|}{ Total $\mathrm{N}=60 \mathrm{mM}$} & \multirow{2}{*}{ 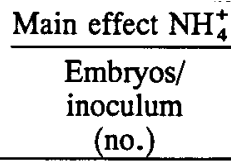 } \\
\hline & & & $\mathrm{NH}_{4}^{+} / \mathrm{N}$ & $\begin{array}{c}\text { Embryos/ } \\
\text { inoculum } \\
\text { (no.) }\end{array}$ & $\mathrm{NH}_{4}^{+} / \mathrm{N}$ & $\begin{array}{c}\text { Embryos/ } \\
\text { inoculum } \\
\text { (no.) }\end{array}$ & \\
\hline 0 & 20 & 0.0 & 0.0 & 3.8 & 0.0 & 2.4 & 3.1 \\
\hline 5 & 20 & 0.25 & 0.13 & 5.9 & 0.08 & 3.4 & 4.8 \\
\hline 10 & 20 & 0.50 & 0.25 & 6.8 & 0.17 & 6.1 & 6.4 \\
\hline 20 & 20 & 1.00 & 0.50 & 5.8 & 0.33 & 5.1 & 5.5 \\
\hline & & & & $\mathrm{L}^{*}$ & & $\mathrm{~L}^{*}$ & $\mathrm{~L}^{*} \mathrm{Q}^{*}$ \\
\hline
\end{tabular}

${ }^{2}$ Statistical analysis used the component of variance method: Significance $=\mathrm{F}$ test, $\mathrm{L}^{*}=$ linear at $P=0.05, \mathrm{Q}^{*}=$ quadratic at $P=0.05$; Main effect of total $\mathrm{N}$ and interaction total $\mathrm{N} \times \mathrm{NH}_{4}^{+}$were not significant at $P=0.05$.

yInocula were 1-mg embryogenic callus fragments subcultured from callus proliferation media containing $20 \mathrm{mM} \mathrm{NH}_{4}^{+}$and $60 \mathrm{mM}$ total $\mathrm{N}$.

opment separately. First, the best embryogenic callus growth obtained with high levels of 10 to $20 \mathrm{~mm}$ ammonium was further promoted by increasing $\mathrm{K}$ from $20 \mathrm{~mm}$ to a 40 to $60 \mathrm{~mm}$ range. Second, the development of embryos triggered by the removal of 2,4-D and BA was enhanced by decreasing ammonium from 20 to $10 \mathrm{~mm}$. We also demonstrated that while decreasing ammonium levels affected embryo development, decreasing levels of the metabolically competing $\mathrm{K}$ ion had no effect. Our experiments also show that the companion ions $\mathrm{Na}^{+}$an $\mathrm{Cl}^{-}$at concentrations up to $40 \mathrm{~mm}$ have no deleterious effects on somatic embryo development.

Our results demonstrate that embryo production of species such as sweetpotato can be greatly improved by optimizing the inorganic constituents of the culture media. Our recommendation for sweetpotato is to grow embryogenic callus by subculture every 8 weeks on a basal $\mathrm{CP}$ medium modified to contain 20 $\mathrm{mm} \mathrm{NH}{ }_{4}^{+}$and $50 \mathrm{~mm} \mathrm{~K}+$ with a total $\mathrm{N}$ of $60 \mathrm{~mm}$. The medium for embryo production should be a basal EP medium modified to contain $10 \mathrm{mMNH}_{4}^{+}$and $20 \mathrm{mM} \mathrm{K}^{+}$with a total $\mathrm{N}$ of 40 mM.

\section{Literature Cited}

Ammirato, P.V. 1983. Embryogenesis, p. 82-123. In: D.A. Evans et al. (eds.) Handbook of plant cell culture Macmillan, New York.

Brown, S., D.F. Wetherell, and D.K. Dougall. 1976. The potassium requirement for growth and embryogenesis in wild carrot suspension cultures. Physiol. Plant. 37:73-79.

Cantliffe, D.J., J.R. Liu, and J.R. Schultheis. 1988. Development of artificial seed of sweet potato for clonal propagation through somatic embryogenesis, p. 183-195. In: W.H. Smith and J.R. Frank (eds.). Methane from biomass: a systems approach. Elsevier, New York.

Chaleff, R.S. 1983. Induction, maintenance, and differentiation of rice callus cultures on ammonium as sole nitrogen source. Plant Cell Tissue Organ Cult. 2:29-37.

Chée, R.P. and D.J. Cantliffe. 1988a. Somatic embryony patterns and plant regeneration i nIpomoea batatas Poir. In Vitro Cell. Dev. Biol. 24:955-958.

Chée, R.P. and D.J. Cantliffe. 1988b. Selective enhancement of Ipomoea batatas Poir. embryogenic and non-embryogenic callus growth and production of embryos in liquid culture. Plant Cell Tissue Organ cult. 15:149-159.

Christianson, M.L. 1985. An embryogenic culture of soybean: towards a general theory of somatic embryogenesis, p. 83-103. In: R.R. Henke et al. (eds.). Tissue culture in forestry and agriculture. Plenum, New York.

Clarkson, D.T. and J.B. Hanson. 1980. The mineral nutrition of higher plants. Annu. Rev. Plant Physiol. 31:239-298.

Dougall, D.K. and D.C. Verma. 1978. Growth and embryo formation in wild-carrot suspension cultures with ammonium as sole nitrogen source. In Vitro Cell. Dev. Biol. 14:180-182.

Fukunaga, Y., J. King, and J.J. Child. 1978. The different effects TCA-cycle acids on the growth of plant cells cultured in liquid media containing various nitrogen sources. Planta 139:199-202. 
Galzy, R. 1972. Remarques sur la nutrition minérale des apex de Vitis rupestris. C.R. Acad. Sc. Paris 275:561-564.

Gamborg, O.L. and J.P. Shyluk. 1970. The culture of plant cells with ammonium salts as sole nitrogen source. Plant Physiol. 45:598-600.

Halperin, W. 1966. Alternative morphogenetic events in cell suspensions. Amer. J. Bot. 53:443-453.

Halperin, W. and D.F. Wetherell. 1965. Ammonium requirement for somatic embryogenesis in vitro. Nature (London) 205:519-520.

Heller, R. 1953. Recherches sur la nutrition minérale des tissus végétaux cultivés in vitro. Ann. Sci. Natl. Bot. Biol. Veg. 14:1223 .

Liu, J.R. and D.J. Cantliffe. 1984. Somatic embryogenesis and plant regeneration in time culture of sweet potato (Ipomoea batatas Poir.). Plant Cell Rpt. 3:112-115.

Marschner, H. 1986. Mineral nutrition of higher plants. Academic, New York. p. 71-114.

Martin, S.M., D. Rose, and V. Hui. 1977. Growth of plant cell suspension cultures with ammonium as sole source of nitrogen. Can. J. Bot. 55:2838-2843.

Murashige, T. and F. Skoog. 1962. A revised medium for rapid growth and bio-assays with tobacco tissue cultures. Physiol. Plant. 15:473497.
O’Neill, S.D. and R.M. Spanswick. 1984. Characterization of native and reconstitutive plasma membrane $\mathrm{H}^{+}$-ATPase from the plasma membrane of Beta vulgaris. J. Membr. Biol. 79:245-256.

Poole, R.J. 1978. Energy coupling for membrane transport. Annu. Rev. Plant. Physiol. 29:437-460.

Seitz Kris, M.H. and E.T. Bingham. 1988. Interactions of highly regenerative genotypes of alfalfa (Medicago sativa) and tissue culture protocols. In Vitro Cell. Dev. Biol. 24:1047-1052.

Spanswick, R.M. 1981. Electronic ion pumps. Annu. Rev. Plant Physiol. 32:267-289.

Tazawa, M. and J. Reinert. 1969. Extracellular and intracellular chemical environments in relation to embryogenesis in vitro. Protoplasm $68: 157-173$

Vasil, I.K. 1984. Cell culture and somatic cell genetics of plants. Plant regeneration and genetic variability. Academic, New York. p. 1926.

Walker, K.A. and S.J. Sato. 1981. Morphogenesis in callus tissue of Medicago sativa: the role of ammonium ion in somatic embryogenesis. Plant Cell Tissue Organ Cult. 1:109-121.

Wetherell, D.F. and D.K. Dougall. 1976. Sources of nitrogen sup, porting growth and embryogenesis in cultured wild carrot tissue. Physiol. Plant 37:97-103. 